\title{
Determination of paracetamol in pharmaceutical samples by spectrophotometric method
}

Chand Pasha

Department of General Studies, Royal Commission Yanbu Colleges and Institutes, Royal Commission for Jubail and Yanbu, P.O. 30436, Yanbu21477, Saudi Arabia

${ }^{+}$Corresponding author: Chand Pasha, Phone: +966531810596, Email address: drcpasha@gmail.com

\section{ARTICLE INFO}

Article history:

Received: December 23, 2019

Accepted: February 14, 2020

Published: July 1, 2020

\section{Keywords:}

1. spectrophotometry

2. diazotization

3. paracetamol

4. p-aminophenol

5. 1, 3 dinitrobenzene

6. 2, 4 dinitrophenyl hydrazine

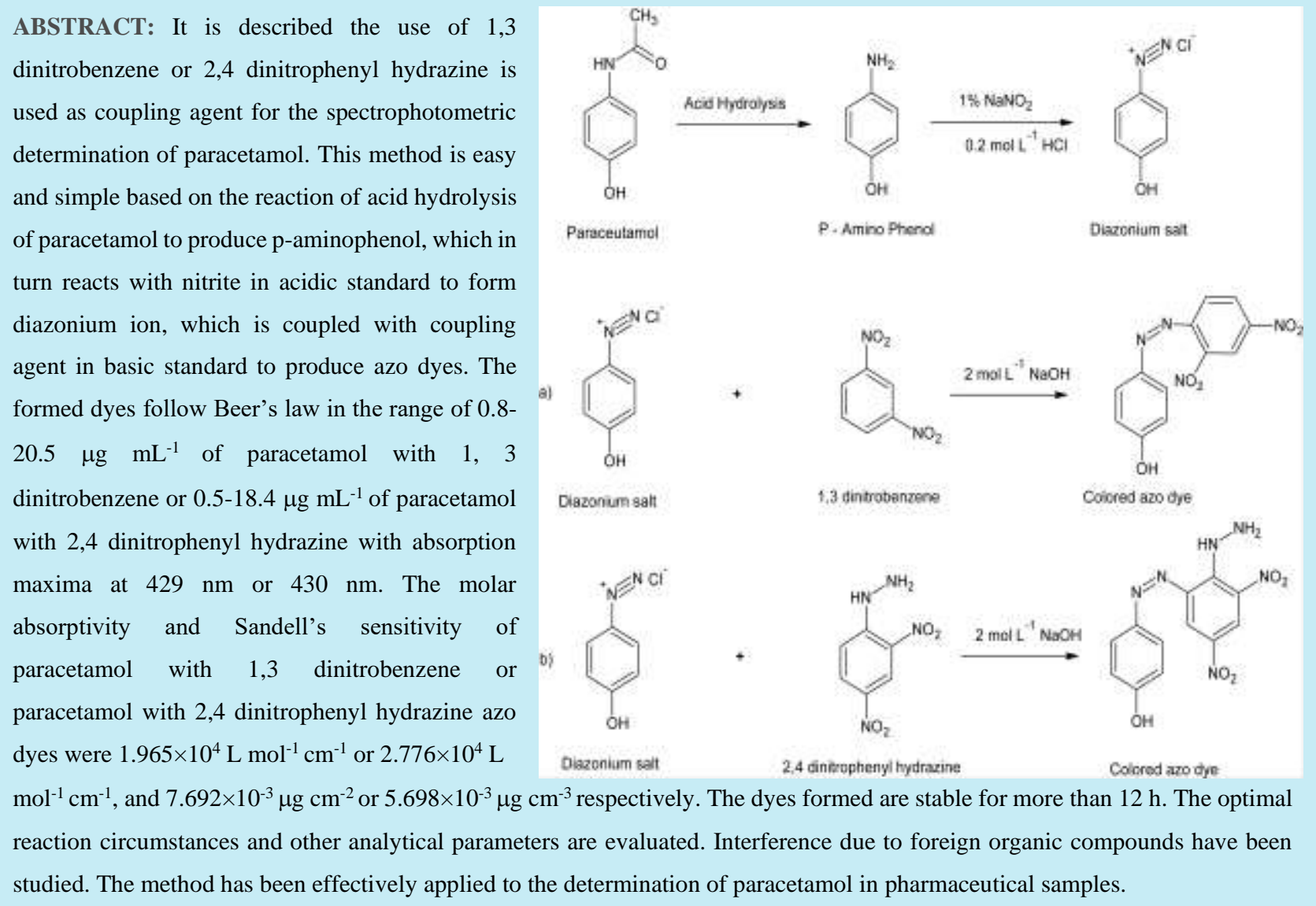

\section{Introduction}

Paracetamol called acetaminophen or 4acetamidophenol, is a common pain reliever and fever reduction medicine ${ }^{1}$. Its chemical name is $\mathrm{N}$ acetyl-p-aminophenol with a chemical formula $\mathrm{C}_{8} \mathrm{H}_{9} \mathrm{NO}_{2}$. Paracetamol was first prepared in 1878 by Harmon Northrop Morse an American chemist ${ }^{2}$.
It is available as a generic medication with trade names including Tylenol and Panadol, among others $^{3}$. It is often sold in the commercial markets with a major ingredient in many cold and flu remedial combination drugs. It is usually used either by mouth or rectally, but is also available intravenously ${ }^{1,4}$. Paracetamol is accessible in as a tablet, drops, capsules, injection, and syrup ${ }^{5}$. 
Paracetamol is usually safe at suggested doses ${ }^{6}$. The suggested maximum daily dosage for an adult is 3 or 4 grams $^{7,8}$. Higher doses may result in toxicity, including liver disaster. Serious skin rashes may infrequently occur, and it appears to be secure during pregnancy and breastfeeding ${ }^{1}$.

Paracetamol is also used for severe ache, such as cancer ache and ache after surgery, in combination with opioid ache medication? Paracetamol has a highly targeted action in the brain, blocking an enzyme involved in the transmission of ache. Its mode of action was known to be different compared to other pain relievers, but although it produces pain relief throughout the body $^{10}$. It is on the WHO's List of essential medicines, the most effective and safe medicines desired in a health system ${ }^{11}$.

A lot of techniques are existing in the literature for the determination of paracetamol in various types of pharmaceutical preparations. These techniques are titrimetric ${ }^{12}$, HPLC and RPHPLC $^{13-15}$, HPTLC $^{16}$, Voltametric $^{17-20}$, electrochemical $^{21}$ and spectrophotometry ${ }^{10}$. Several spectrophotometric techniques for the determination of paracetamol are presented in the literature ${ }^{10,22-41}$.

The reagents reported for the spectrophotometric determination of paracetamol are less selective, less sensitive and some require stringent experimental conditions and are chronic toxic in nature ${ }^{27,33,36,38}$. The present research work is on spectrophotometric determination of paracetamol in pharmaceutical samples. The hydrolyzed product of paracetamol is diazotized with nitrite in acidic standard at room temperature and the diazonium salt thus shaped is coupled with 1,3 dinitrobenzene and 2,4 dinitrophenyl hydrazine to give colored azo dye in alkaline standard is the source for the determination of paracetamol. The method has been successfully applied to the determination of paracetamol in pharmaceutical samples.

\section{Experimental}

\subsection{Instruments used}

A SHIMADZU Deutschland GmbH UV-2550 spectrophotometer and a pH meter- WTW pH 330 were used.

\subsection{Chemicals and reagents used}

Stock solution of paracetamol (Gift sample from Matrix Laboratory, Hyderabad, India): Weighed an amount $0.251 \mathrm{~g}$ of paracetamol and was dissolved in 10-15 mL of ethanol then the solution is transferred into a $250 \mathrm{~mL}$ standard flask, fulfilled to the mark with double distilled water $\left(1000 \mu \mathrm{g} \mathrm{mL}^{-1}\right)$. Working solution was prepared as required by dilution.

Sodium nitrite solution $(0.5 \%)$, hydrochloric acid solution $\left(0.5 \mathrm{~mol} \mathrm{~L}^{-1}\right), 1,3$ dinitrobenzene or 2,4 dinitrophenyl hydrazine solution ( $2 \%$ ), sodium hydroxide solution $\left(2 \mathrm{~mol} \mathrm{~L}^{-1}\right)$.

\subsection{Hydrolyzed paracetamol solution $\left(100 \mu \mathrm{g} \mathrm{mL^{-1 }}\right)$}

A $150 \mathrm{~mL}$ of $1000 \mu \mathrm{g} \mathrm{mL}-1$ paracetamol solution was transferred to $250 \mathrm{~mL}$ round bottomed flask provided with $20 \mathrm{~mL}$ of $4 \mathrm{~mol} \mathrm{~L}^{-1}$ of hydrochloric acid, then refluxed for $1 \mathrm{~h}$, kept aside to cool the solution, then neutralized with $20 \%$ of sodium carbonate solution, then diluted with distilled water using a $250 \mathrm{~mL}$ volumetric flask. A $16.6 \mathrm{~mL}$ of the above solution was diluted with distilled water in a $100 \mathrm{~mL}$ volumetric flask to prepare $100 \mu \mathrm{g} \mathrm{mL}^{-1}$ paracetamol $^{40}$.

\subsection{Paracetamol tablets solution $\left(1000 \mu \mathrm{g} \mathrm{mL}^{-1}\right)$}

Paracetamol tablets of different trademarks were purchased from local pharmacy and were finely powdered. An accurately weighed amount of powder equivalent to $0.25 \mathrm{~g}$ paracetamol was dissolved in $10-12 \mathrm{~mL}$ ethanol, then $90-100 \mathrm{~mL}$ distilled water was added, mixed well to increase the solubility, filtered into $250 \mathrm{~mL}$ calibrated flask. Then the solution was completed to the mark with distilled water, and progress as mentioned above in preparation of hydrolyzed paracetamol solution ${ }^{40}$.

\subsection{Paracetamol tablets of different trademarks used}

P-750: 750 mg. Apex Laboratories Pvt. Ltd. Chennai, TamilNadu, INDIA, Dolopar: $650 \mathrm{mg}$. Micro LabsLtd. Bangalore, INDIA, Disprin Paracetamol: $500 \mathrm{mg}$. Reckitt \& Benckiser Ltd. Gurgaon, Haryana, INDIA, Crocin Quik: 500 mg. Glaxo Smithkline, Mumbai, Maharashtra, INDIA, Paramet: $500 \mathrm{mg}$. Wallace Pharmaceuticals Ltd. Goa, INDIA, Nicetamol: 125 mg. Dr. Reddy's Laboratories Ltd, Hyderabad, Andra Pradesh, 
INDIA, Paracip 500 mg. Cipla Limited, Mumbai, Maharashtra, INDIA.

\subsection{Procedure for the determination of paracetamol}

An aliquot of the solution containing paracetamol $\left(\mu \mathrm{g} \mathrm{mL}^{-1}\right)$ was transferred into a string of $10 \mathrm{~mL}$ calibrated flasks. Add $1 \mathrm{~mL}$ of $0.5 \%$ solution of $\mathrm{NaNO}_{2}$ and $0.5 \mathrm{~mL}$ of $0.5 \mathrm{~mol} \mathrm{~L}^{-1} \mathrm{HCl}$ and then the solution was mixed thoroughly and kept away for accomplishment of diazotization reaction. Then, add $1 \mathrm{~mL}$ of $2 \% 1,3$ dinitrobenzene or 2,4 dinitrophenyl hydrazine and $1.5 \mathrm{~mL}$ of $2 \mathrm{~mol}$ $\mathrm{L}^{-1} \mathrm{NaOH}$ solutions and then diluted to $10 \mathrm{~mL}$, using distilled water, and mixed thoroughly. Later the absorbance of the colored azo dye formed was measured at $429 \mathrm{~nm}$ or $430 \mathrm{~nm}$ beside the reagent blank.

\section{Results and Discussion}

The diazotization of paracetamol with nitrite, followed by the coupling of 1,3 dinitrobenzene or 2,4 dinitrophenyl hydrazine in alkaline standard. The absorption spectra of the azo dye produced between paracetamol-1,3 dinitrobenzene or 2,4 dinitrophenyl hydrazine is presented in Fig. 1 having absorption maximum at $429 \mathrm{~nm}$ or $430 \mathrm{~nm}$, respectively. The plot of absorbance against concentration of paracetamol coupled with 1, 3dinitrobenzene or 2,4 dinitrophenyl hydrazine is presented in Fig. 2. The formed dyes obeys Beer's law in the range of $0.8-20.5 \mu \mathrm{g} \mathrm{mL}^{-1}$ of paracetamol with 1,3 dinitrobenzene or $0.5-18.4 \mu \mathrm{g} \mathrm{mL}^{-1}$ of paracetamol with 2,4 dinitrophenyl hydrazine and the reaction method is shown in Scheme 1.

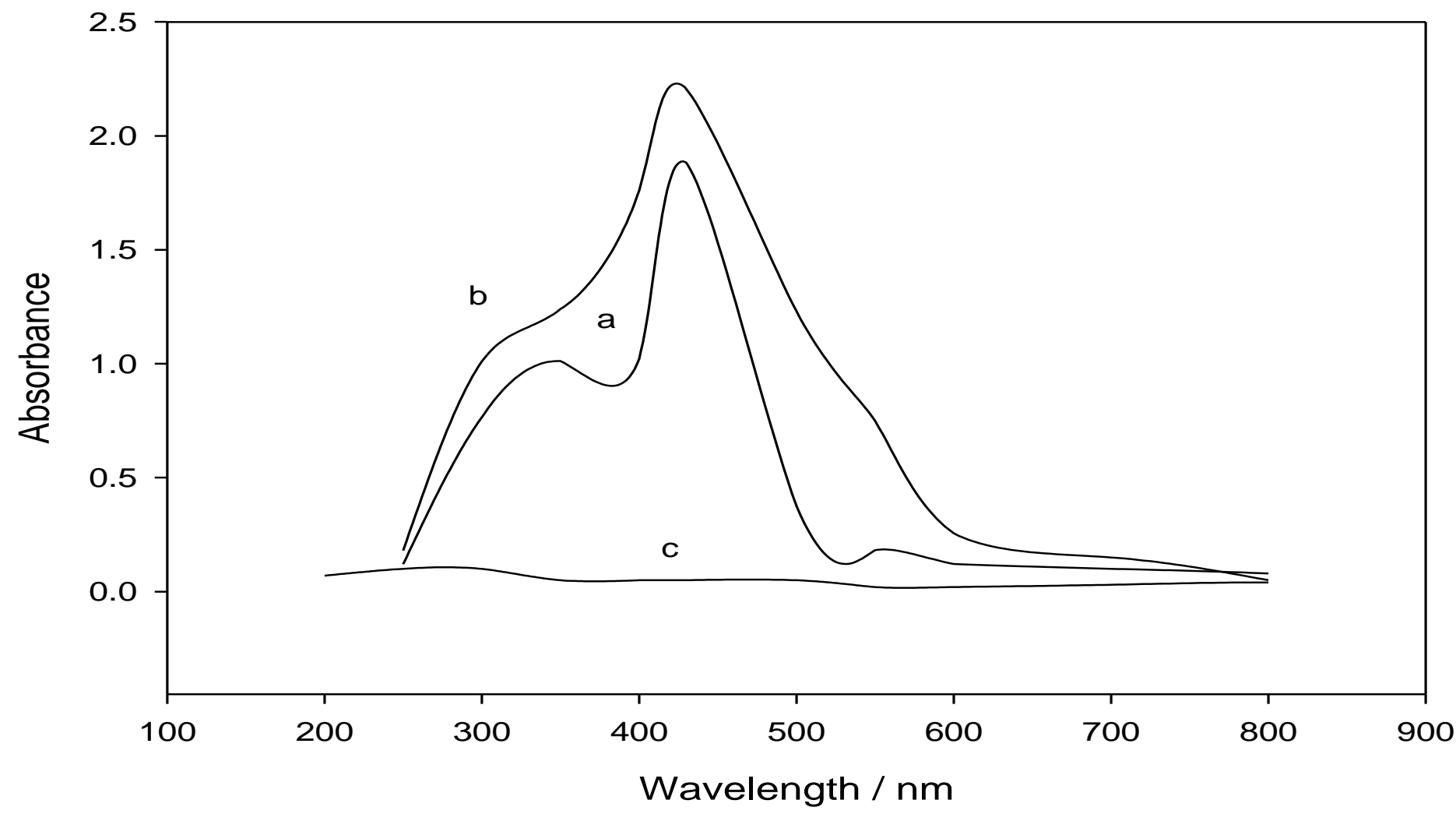

Figure 1. Absorption spectrum of the diazocouple of nitrite with 1,3 dinitrobenzene against reagent blank (a); absorption spectrum of the diazocouple of nitrite with 2,4 dinitrophenyl hydrazine against reagent blank (b) and reagent blank against distilled water (c). 


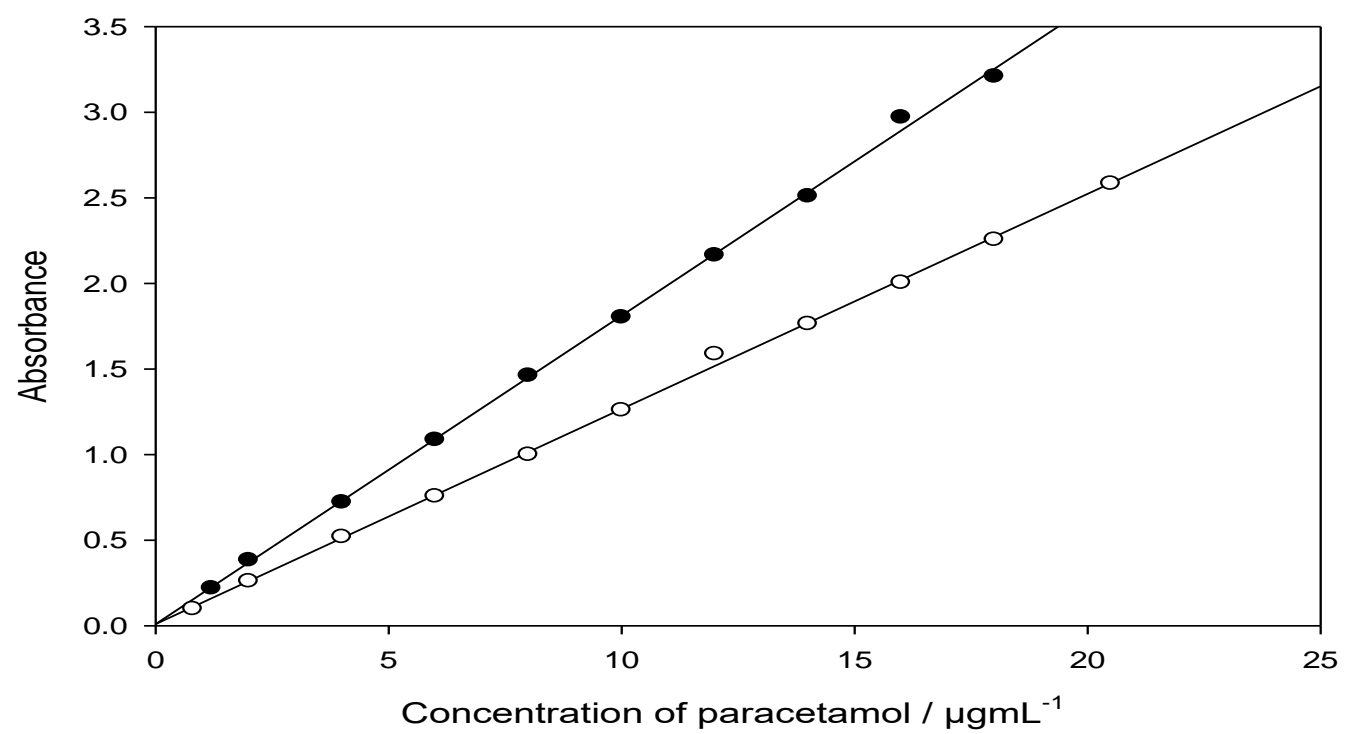

- Beer's law using paracetamol coupled with 2,4 dinitrophenyl hydrazine - Beer's law using paracetamol coupled with 1,3 dinitrobenzene

Figure 2. Adherence to Beer's law using 1,3 dinitrobenzene or 2,4 dinitrophenyl hydrazine as coupling agents.<smiles>CC(=O)Nc1ccc(O)cc1</smiles><smiles>Nc1ccc(O)cc1</smiles><smiles>O=[N+]([O-])O[N+](=O)[O-]</smiles>

- Amino Phenol<smiles>O=[N+]([O-])c1cccc([N+](=O)[O-])c1</smiles>

1,3 dinitrobenzene<smiles>NNc1ccc([N+](=O)[O-])cc1[N+](=O)[O-]</smiles>

2,4 dinitrophenyl hydrazine
Diazonium salt<smiles>[N-]=[N+]c1ccc(O)cc1</smiles>

a)<smiles>[N-]=[N+]c1ccc(O)cc1</smiles>

Diazonium salt

Scheme 1. Formation of colored azo dye<smiles>[N-]=[N+]c1ccc(O)cc1</smiles>

Diazonium salt

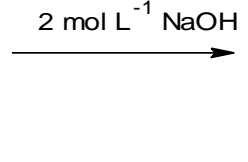

Colored azo dye<smiles>O=[N+]([O-])c1ccc(/N=N\c2ccc(O)cc2)c([N+](=O)[O-])c1</smiles>

Colored azo dye<smiles>NNc1c(/N=N\c2ccc(O)cc2)cc([N+](=O)[O-])cc1[N+](=O)[O-]</smiles> 


\subsection{Effect of acid concentration, acids and temperature}

The acidity effect on the diazotization reaction was considered with $2 \mu \mathrm{g} \mathrm{mL}^{-1}$ of paracetamol, in the range $0.1-0.6 \mathrm{~mol} \mathrm{~L}^{-1} \mathrm{HCl}$. From the results, it can be observed that $0.5 \mathrm{~mL}$ of $0.5 \mathrm{~mol} \mathrm{~L}^{-1} \mathrm{HCl}$ is the suitable concentration which gives the highest value of absorbance, for diazocouple of nitrite with 1,3 dinitrobenzene or 2,4 dinitrophenyl hydrazine, beyond this range, a decrease in the absorbance was detected (Tab. 1).

Table 1. Effect of acid concentration on absorbance.

\begin{tabular}{|c|c|c|}
\hline $\begin{array}{c}\mathbf{0 . 5} \mathbf{~ m L} \\
\mathbf{H C l} \text { used } \\
\left(\mathbf{m o l ~ L}^{-1}\right)\end{array}$ & $\begin{array}{c}|c| \\
\text { 1,3 dinitrobenzene }\end{array}$ & $\begin{array}{c}\text { 2,4 dinitrophenyl } \\
\text { hydrazine }\end{array}$ \\
\hline 0.1 & 0.226 & 0.202 \\
\hline 0.2 & 0.243 & 0.215 \\
\hline 0.3 & 0.259 & 0.236 \\
\hline 0.4 & 0.253 & 0.238 \\
\hline 0.5 & 0.285 & 0.242 \\
\hline 0.6 & 0.271 & 0.234 \\
\hline
\end{tabular}

The effect of the amount of different acid (weak and strong) for the diazotization of paracetamol with nitrite, followed by the coupling of 1,3 dinitrobenzene or 2,4 dinitrophenyl hydrazine have been investigated. The results indicated that $0.5 \mathrm{~mL}$ of $0.5 \mathrm{~mol} \mathrm{~L}^{-1} \mathrm{HCl}$ produces the highest intensity for the dye, so it has been selected in the subsequent experiments (Tab. 2). Diazotization was conceded at room temperature $(25 \pm 5){ }^{0} \mathrm{C}$.

Table 2. Effect of different acid concentration on absorbance.

\begin{tabular}{|c|c|c|c|c|}
\hline $\begin{array}{c}\mathbf{0 . 5} \text { mol L }^{-1} \\
\text { acid concen- } \\
\text { tration used }\end{array}$ & \multicolumn{4}{|c|}{ Absorbance $(\mathbf{A}) / \mathbf{m L}$ of acid used } \\
\cline { 2 - 5 } & 0.25 & $0.5 \mathrm{~mL}$ & $0.75 \mathrm{~mL}$ & $1.0 \mathrm{~mL}$ \\
\hline $\mathrm{mLl}$ & 0.222 & 0.252 & 0.244 & 0.201 \\
\hline $\mathrm{HNO}_{3}$ & 0.217 & 0.243 & 0.237 & 0.296 \\
\hline $\mathrm{H}_{2} \mathrm{SO}_{4}$ & 0.215 & 0.222 & 0.219 & 0.263 \\
\hline $\mathrm{CH}_{3} \mathrm{COOH}$ & 0.297 & 0.217 & 0.295 & 0.212 \\
\hline
\end{tabular}

\subsection{Effect of the nitrite concentration}

The color is reached maximum intensity when using $1 \mathrm{~mL}$ of $0.5 \%$ sodium nitrite solution using paracetamol-1,3 dinitrobenzene or 2,4 dinitrophenyl hydrazine with $2 \mu \mathrm{g} \mathrm{mL} \mathrm{mL}^{-1}$ of paracetamol and adding $1 \mathrm{~mL}$ of $0.1-1.0 \%$ solutions of the nitrite in hydrochloric acid $(0.5 \mathrm{~mol}$ $\left.\mathrm{L}^{-1}\right)$ to a series of nitrite solutions. Higher concentration did not build up the absorbance further, and at lower concentration, no good results were obtained.

\subsection{Effect of coupling agent}

1,3 dinitrobenzene or 2,4 dinitrophenyl hydrazine is used as a coupling agent was in the current procedure, by taking $2 \mu \mathrm{g} \mathrm{mL} \mathrm{mL}^{-1}$ of paracetamol and adding $0.25-2.0 \mathrm{~mL}$ of $2 \% 1,3$ dinitrobenzene or 2,4 dinitrophenyl hydrazine to a string of nitrite solutions. It was found that utmost and firm color was obtained with $1 \mathrm{~mL}$ of 1,3 dinitrobenzene or 2,4 dinitrophenyl hydrazine (2\%) solution in an ultimate volume of $10 \mathrm{~mL}$.

\subsection{Effect of $\mathrm{NaOH}$ concentration}

The experiment showed that $1.5 \mathrm{~mL}$ of $\mathrm{NaOH}$ gave utmost absorbance and $1.5 \mathrm{~mL}$ of $2 \mathrm{~mol} \mathrm{~L}^{-1}$ $\mathrm{NaOH}$ solutions was preferred for the diazotization of paracetamol with nitrite, followed by the coupling of 1,3 dinitrobenzene or 2,4 dinitrophenyl hydrazine using $2 \mu \mathrm{g} \mathrm{mL}^{-1}$ of paracetamol. Other alkaline solutions were applied, but the finest results were gained by the use of $\mathrm{NaOH}$ solution (Tab. 3).

Table 3. Effect of $\mathrm{NaOH}$ on absorbance.

\begin{tabular}{|c|c|c|}
\hline $\begin{array}{c}\mathbf{2} \text { mol L}^{-1} \\
\text { sodium } \\
\text { hydroxide } \\
\text { used (mL) }\end{array}$ & \multicolumn{2}{|c|}{ Absorbance(A) } \\
\hline 0.5 & 0.218 & 0.212 \\
\hline 1.0 & 0.224 & 0.216 \\
\hline 1.5 & 0.257 & 0.232 \\
\hline 2.0 & 0.243 & 0.226 \\
\hline
\end{tabular}

\subsection{Interference of foreign compounds}

The results specified that the studied foreign compounds such as $1000 \mu \mathrm{g} \mathrm{mL}^{-1}$ of glucose, 800 $\mu \mathrm{g} \mathrm{mL}^{-1}$ of fructose, $500 \mu \mathrm{g} \mathrm{mL}^{-1}$ of lactose, $500 \mu \mathrm{g}$ $\mathrm{mL}^{-1}$ of starch and $200 \mu \mathrm{g} \mathrm{mL}^{-1}$ of urea do not interfere in the determination of $2 \mu \mathrm{g} \mathrm{mL} \mathrm{m}^{-1}$ of paracetamol. An error below $\pm 2 \%$ error in the absorbance values of paracetamol at $2 \mu \mathrm{g} \mathrm{mL}^{-1}$. 


\subsection{Analytical data}

By plotting absorbance beside concentration of paracetamol, a straight line is obtained in the graph. Beer's law obeys in the range of $0.8-20.5 \mu \mathrm{g} \mathrm{mL}$ ${ }^{1}$ of paracetamol with 1,3 dinitrobenzene or 0.5$18.4 \mu \mathrm{g} \mathrm{mL}^{-1}$ of paracetamol with 2,4 dinitrophenyl hydrazine. The molar absorptivity of colored system with nitrite-1,3 dinitrobenzene or nitrite-2,4 dinitrophenyl hydrazine were $1.965 \times 10^{4} \mathrm{~L} \mathrm{~mol}^{-}$ ${ }^{1} \mathrm{~cm}^{-1}$ or $2.776 \times 10^{4} \mathrm{~L} \mathrm{~mol}^{-1} \mathrm{~cm}^{-1}$, and the Sandell's sensitivity of colored system with nitrite-1,3 dinitrobenzene or nitrite-2,4 dinitrophenyl hydrazine were found to be $7.692 \times 10^{-3} \mu \mathrm{g} \mathrm{cm}^{-2}$ or $5.698 \times 10^{-3} \mu \mathrm{g} \mathrm{cm}^{-2}$.

The detection limit $\left(\mathrm{D}_{\mathrm{L}}=3.3 \sigma / \mathrm{S}\right)$ and quantitation limit $\left(\mathrm{Q}_{\mathrm{L}}=10 \sigma / \mathrm{S}\right)$ of paracetamol with 1,3 dinitrobenzene or paracetamol with 2,4 dinitrophenyl hydrazine were found to be $0.264 \mu \mathrm{g}$ $\mathrm{mL}^{-1}$ and $0.80 \mu \mathrm{g} \mathrm{mL}^{-1}$ or $0.239 \mu \mathrm{g} \mathrm{mL}^{-1}$ and 0.724 $\mu \mathrm{g} \mathrm{mL}^{-1}$ [where $\sigma=$ Standard Deviation, $(\mathrm{n}=5)$ and $\mathrm{S}=$ Slope of the curve] and correlation coefficient of paracetamol with 1,3 dinitrobenzene or paracetamol with 2,4 dinitrophenyl hydrazine were 0.9991 or 0.9992 .

\subsection{Comparison of the current method with other spectrophotometric methods}

A comparison of the current method with other spectrophotometric methods are reported for paracetamol determination (Tab. 4). As can be seen, the molar absorptivity, Sandell's sensitivity and color stability (more than $12 \mathrm{~h}$ ) of the proposed method are comparable or better than other reported methods. The proposed method exhibited excellent selectivity, repeatability, and ease of operation. Thus, the presented method could be of great interest especially for determination of paracetamol in routine analytical laboratories.

Table 4. Comparison of the proposed method with other spectrophotometric methods.

\begin{tabular}{|c|c|c|c|c|c|c|}
\hline Reagent used & $\begin{array}{c}\lambda \max / \\
\mathbf{n m}\end{array}$ & $\begin{array}{c}\varepsilon \times 10^{4} / \\
\mathrm{L} \mathrm{mol}^{-1} \mathrm{~cm}^{-1}\end{array}$ & $\begin{array}{l}\text { Beer's law limits / } \\
\qquad \mu \mathrm{g} \mathrm{mL} \mathbf{L}^{-1}\end{array}$ & $\begin{array}{l}\text { Sandell's } \\
\text { sensitivity / } \\
\mu \mathrm{g} \mathrm{cm}^{-2}\end{array}$ & Remarks & Ref. No \\
\hline $\begin{array}{l}\text { 8-hydroxyquinoline } \\
\text { or } \\
\text { 2-naphthol }\end{array}$ & $\begin{array}{l}470 \\
\text { or } \\
490\end{array}$ & $\begin{array}{c}1.9 \\
\text { or } \\
2.46\end{array}$ & $2-10$ & $\begin{array}{l}7.9 \times 10^{-3} \\
\text { or } \\
5.9 \times 10^{-3}\end{array}$ & --- & [10] \\
\hline $\begin{array}{l}\text { 1-napthol } \\
\text { or } \\
\text { resorcinol }\end{array}$ & $\begin{array}{l}505 \\
\text { or } \\
485\end{array}$ & $\begin{array}{l}1.68 \\
\text { or } \\
2.86\end{array}$ & $0-10$ & $\begin{array}{c}9.0 \mathrm{ng} \mathrm{mL}^{-1} \mathrm{~cm}^{-2} \\
\text { or } \\
5.3 \mathrm{n} \mathrm{mL}^{-1} \mathrm{~cm}^{-2}\end{array}$ & $\begin{array}{l}\text { Color stability is } \\
<\text { than } 1 \text { hour }\end{array}$ & [27] \\
\hline sodium bismuthate & $\begin{array}{l}550 \\
\text { or } \\
560\end{array}$ & $\begin{array}{c}77.27 \\
\text { or } \\
100.0\end{array}$ & $\begin{array}{c}100-300 \text { in } \mathrm{HCl} \\
\text { or } \\
300-800 \text { in } \mathrm{CH}_{3} \mathrm{COOH}\end{array}$ & --- & $\begin{array}{c}\text { Lack of Sandell's } \\
\text { sensitivity }\end{array}$ & [33] \\
\hline 2,4-dichloroaniline & 490 & 3219.69 & $4-350$ & --- & $\begin{array}{l}\text { Lack of } \\
\text { application }\end{array}$ & [36] \\
\hline Different solvents & 243 & --- & $1-30 \mathrm{mg} \mathrm{L}^{-1}$ & --- & Less sensitive & [38] \\
\hline Histidine & 430 & 1.118 & $10-500 \mu \mathrm{g} \mathrm{mL}-1$ & 0.0135 & Less selective & [41] \\
\hline $\begin{array}{l}\text { 2,7-dihydroxy } \\
\text { naphthalene }\end{array}$ & 481 & 1.058 & $1-14$ & 0.0142 & --- & [38] \\
\hline $\begin{array}{l}\text { Proposed method } \\
1,3 \text { dinitrobenzene } \\
\text { or } \\
2,4 \text { dinitrophenyl } \\
\text { hydrazine }\end{array}$ & $\begin{array}{l}429 \\
\text { or } \\
430\end{array}$ & $\begin{array}{l}1.965 \\
\text { or } \\
2.776\end{array}$ & $\begin{array}{l}0.8-20.5 \\
\text { or } \\
0.5-18.4\end{array}$ & $\begin{array}{c}7.692 \times 10^{-3} \\
\text { or } \\
5.698 \times 10^{-3}\end{array}$ & --- & \\
\hline
\end{tabular}

\subsection{Applications}

The current scheme was useful for the determination of paracetamol in pharmaceuticals samples. The relative standard deviation for all five samples ranged from $0.53-1.83 \%$ at $95 \%$ confidence. The percentage recoveries were found to the range from $98.20-100.40$. The outcomes were compared with the reference method $^{36,41}$ (Tab. 5). The additional ingredients present in pharmaceutical sample appearances did not form hinder. 
Table 5. Determination of paracetamol in different pharmaceutical samples using 1,3 dinitrobenzene or 2,4 dinitrophenyl hydrazine as coupling agent.

\begin{tabular}{|c|c|c|c|c|c|c|c|}
\hline \multirow[b]{2}{*}{$\begin{array}{l}\text { Pharmaceutical } \\
\text { Samples }\end{array}$} & \multirow[b]{2}{*}{$\begin{array}{l}\text { Sample } \\
\text { taken / } \\
\mu_{\text {gmL }}^{-1}\end{array}$} & \multicolumn{2}{|c|}{ Proposed method } & \multicolumn{2}{|c|}{$\begin{array}{c}\text { Relative Standard Deviation / } \\
\%\end{array}$} & \multicolumn{2}{|c|}{ Recovery / \% of } \\
\hline & & 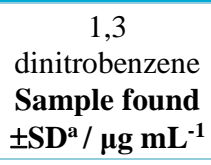 & $\begin{array}{l}\text { 2,4 dinitrophenyl } \\
\text { hydrazine } \\
\text { Sample found } \\
\pm \mathbf{S D}^{\mathbf{a}} / \boldsymbol{\mu g} \mathbf{~ m L} \mathbf{L}^{-1}\end{array}$ & $\begin{array}{c}1,3 \\
\text { dinitrobenzene }\end{array}$ & $\begin{array}{c}2,4 \\
\text { dinitropheny } \\
\text { lhydrazine }\end{array}$ & $\begin{array}{c}1,3 \\
\text { dinitrobenzene }\end{array}$ & $\begin{array}{c}2,4 \\
\text { dinitrophenyl } \\
\text { hydrazine }\end{array}$ \\
\hline $\begin{array}{c}\mathrm{P}-750 \\
(750 \mathrm{mg} / \mathrm{tab})\end{array}$ & $\begin{array}{c}5.0 \\
10.0 \\
15.0\end{array}$ & $\begin{array}{l}5.00 \pm 0.04 \\
9.98 \pm 0.06 \\
14.96 \pm 0.08\end{array}$ & $\begin{array}{l}4.96 \pm 0.05 \\
9.94 \pm 0.07 \\
14.92 \pm 0.09\end{array}$ & $\begin{array}{l}0.80 \\
0.60 \\
0.53\end{array}$ & $\begin{array}{l}1.00 \\
0.70 \\
0.60\end{array}$ & $\begin{array}{l}100.00 \\
99.80 \\
99.73\end{array}$ & $\begin{array}{l}99.20 \\
99.40 \\
99.46\end{array}$ \\
\hline $\begin{array}{c}\text { Dolopar } \\
(650 \mathrm{mg} / \mathrm{tab})\end{array}$ & $\begin{array}{c}5.0 \\
10.0 \\
15.0\end{array}$ & $\begin{array}{l}5.01 \pm 0.05 \\
9.95 \pm 0.08 \\
14.94 \pm 0.09\end{array}$ & $\begin{array}{l}5.00 \pm 0.08 \\
9.91 \pm 0.08 \\
14.90 \pm 0.10\end{array}$ & $\begin{array}{l}0.99 \\
0.80 \\
0.60\end{array}$ & $\begin{array}{l}1.60 \\
0.81 \\
0.67\end{array}$ & $\begin{array}{c}100.20 \\
99.50 \\
99.60\end{array}$ & $\begin{array}{l}100.00 \\
99.10 \\
99.33\end{array}$ \\
\hline $\begin{array}{c}\text { Disprin } \\
\text { Paracetamol } \\
(500 \mathrm{mg} / \mathrm{tab})\end{array}$ & $\begin{array}{c}5.0 \\
10.0 \\
15.0\end{array}$ & $\begin{array}{l}4.97 \pm 0.06 \\
9.97 \pm 0.08 \\
14.98 \pm 0.09\end{array}$ & $\begin{array}{c}4.92 \pm 0.09 \\
9.90 \pm 0.10 \\
14.93 \pm 0.10\end{array}$ & $\begin{array}{l}1.21 \\
0.80 \\
0.60\end{array}$ & $\begin{array}{l}1.83 \\
1.01 \\
0.67\end{array}$ & $\begin{array}{l}99.40 \\
99.70 \\
99.87\end{array}$ & $\begin{array}{l}98.40 \\
98.60 \\
99.53\end{array}$ \\
\hline $\begin{array}{l}\text { CrocinQuik } \\
(500 \mathrm{mg} / \mathrm{tab})\end{array}$ & $\begin{array}{c}5.0 \\
10.0 \\
15.0\end{array}$ & $\begin{array}{l}5.01 \pm 0.06 \\
9.99 \pm 0.09 \\
14.98 \pm 0.10\end{array}$ & $\begin{array}{l}4.91 \pm 0.07 \\
9.89 \pm 0.11 \\
14.92 \pm 0.12\end{array}$ & $\begin{array}{l}1.19 \\
0.90 \\
0.67\end{array}$ & $\begin{array}{l}1.42 \\
1.11 \\
0.80\end{array}$ & $\begin{array}{c}100.20 \\
99.90 \\
99.86\end{array}$ & $\begin{array}{l}98.20 \\
98.90 \\
99.46\end{array}$ \\
\hline $\begin{array}{c}\text { Paramet } \\
(500 \mathrm{mg} / \mathrm{tab})\end{array}$ & $\begin{array}{c}5.0 \\
10.0 \\
15.0\end{array}$ & $\begin{array}{l}4.99 \pm 0.08 \\
10.00 \pm 0.08 \\
14.96 \pm 0.09\end{array}$ & $\begin{array}{c}4.94 \pm 0.04 \\
9.88 \pm 0.07 \\
14.87 \pm 0.10\end{array}$ & $\begin{array}{l}1.60 \\
0.80 \\
0.60\end{array}$ & $\begin{array}{l}0.81 \\
0.71 \\
0.67\end{array}$ & $\begin{array}{c}99.80 \\
100.00 \\
99.73\end{array}$ & $\begin{array}{l}98.80 \\
98.80 \\
99.13\end{array}$ \\
\hline $\begin{array}{l}\text { Nicetamol } \\
(125 \mathrm{mg} / \mathrm{tab})\end{array}$ & $\begin{array}{c}5.0 \\
10.0 \\
15.0\end{array}$ & $\begin{array}{c}5.02 \pm 0.08 \\
9.92 \pm 0.08 \\
14.99 \pm 0.09\end{array}$ & $\begin{array}{l}4.97 \pm 0.08 \\
9.96 \pm 0.09 \\
14.83 \pm 0.09\end{array}$ & $\begin{array}{l}1.59 \\
0.81 \\
0.60\end{array}$ & $\begin{array}{l}1.61 \\
0.90 \\
0.61\end{array}$ & $\begin{array}{c}100.40 \\
99.20 \\
99.93\end{array}$ & $\begin{array}{l}99.40 \\
99.60 \\
98.87\end{array}$ \\
\hline $\begin{array}{c}\text { Paracip } \\
(500 \mathrm{mg} / \mathrm{tab})\end{array}$ & $\begin{array}{c}5.0 \\
10.0 \\
15.0\end{array}$ & $\begin{array}{c}4.97 \pm 0.06 \\
9.94 \pm 0.08 \\
14.94 \pm 0.10\end{array}$ & $\begin{array}{c}4.93 \pm 0.09 \\
9.83 \pm 0.06 \\
14.85 \pm 0.09\end{array}$ & $\begin{array}{l}1.21 \\
0.80 \\
0.66\end{array}$ & $\begin{array}{l}1.82 \\
0.61 \\
0.60\end{array}$ & $\begin{array}{l}99.40 \\
99.40 \\
99.60\end{array}$ & $\begin{array}{l}98.60 \\
98.30 \\
99.00\end{array}$ \\
\hline
\end{tabular}

a. Mean $(\mathrm{n}=5) \pm \mathrm{SD}\{$ standard deviation $\}$.

\section{Conclusions}

This study demonstrated that spectrophotometric analysis is a very powerful methodology for the determination of paracetamol. For the first time 1,3 dinitrobenzene or 2,4 dinitrophenyl hydrazine is used as coupling agent for the determination of paracetamol in pharmaceutical dosage samples using an easy and simple spectrophotometric method. The proposed method has an ample range of applications with no need of heating, cooling, extraction and has high color stability $(12 \mathrm{~h})$. The percentage recoveries were found in the range from $98.20-100.40$ which complete the legitimacy of the method for the analysis of paracetamol in pharmaceutical formulations. Moreover, the current method is more effective than the methods reported in the literature and has been effectively applied to the spectrophotometric analysis of determination of paracetamol in several pharmaceutical dosage samples.

\section{Acknowledgment}

Author is thankful to the department of General Studies, Yanbu Industrial College and RCYCI, Yanbu, KSA, for the constant support and encouragement.

\section{References}

[1] Acetaminophen. The American Society of Health System Pharmacists.Archivedfrom the original on 5 June 2016. Retrieved16 September 2016.

[2] Mangus, B. C., Miller, M. G., Pharmacology application in athletic training, F.A. Davis, Philadelphia, 2005.

[3] Hamilton, R. J., Tarascon Pocket Pharmacopoeia 2013 Classic Shirt Pocket Edition, Jones \& Bartlett Learning, Burlington, $27^{\text {th }}$ ed., 2013.

[4] Tobias, J. S., Hochhauser, D., Cancer \& Its Management, Wiley-Blackwell, New Jersey, 7th ed., 2014. https://www.wiley.com/enus/Cancer+and+its+Management $\% 2 \mathrm{C}+7$ th+Edition-p9781118468739 . 
[5] Sweetman, S. C., The Complete Drug Reference, The Pharmaceutical Press, London,36 ${ }^{\text {th }}$ ed., 2009. https://www.worldcat.org/title/martindale-thecomplete-drug-reference/oclc/780989871.

[6] Russell, F., M., Shann, F., Curtis, N., Mulholland, K., Evidence on the use of paracetamol in febrile children, Bulletin of the World Health Organization 81 (5) (2003) 367-372. http://researchonline.lshtm.ac.uk/13082/.

[7] Paracetamol for adults, ache killer to treat aches, aches and fever - NHS.UK. Archivedfrom the original on August 22, 2017. Retrieved August 22,2017. https://en.wikipedia.org/wiki/Paracetamol.

[8] Farrell, S. E., What are the recommended maximum daily dosages of acetaminophen in adults and children? Medscape, 2020. https://www.medscape.com/answers/82020027207/what-are-the-recommended-maximum-dailydosages-of-acetaminophen-in-adults-and-children.

[9] Scottish Intercollegiate Guidelines Network (SIGN) 2008. Guideline 106, Control of ache in adults with cancer. Scotland: National Health Service (NHS). ISBN 9781905813384, Archived from the original on 201012-20. https://en.wikipedia.org/wiki/Paracetamol.

[10] Dixit, R. B., Patel, J. A., Spectrophotometric determination of paracetamol drug using 8hydroxyquinoline, International Journal of Pharmaceutical Sciences and Research 5 (6) (2014) 2393-2397. https://doi.org/10.13040/IJPSR.09758232.5(6).2393-97.

[11] WHO Model List of Essential Medicines (19th List), 2015. Archived (PDF) from the original on 13 December 2016. Retrieved 8 December 2016. https://en.wikipedia.org/wiki/Paracetamol.

[12] Sethi, P. D., Quantitative Analysis of Drugs in Pharmaceutical Formulations, CBS Publishers, New Delhi, 1997. https://link.springer.com/article/10.1208/pt050455.

[13] Topkafa, M., Ayyildiz, H. F., Memon, F. N., Kara, H., New potential humic acid stationary phase toward drug components: Development of a chemometricassisted RP-HPLC method for the determination of paracetamol and caffeine in tablet formulations, Journal of Separation Science 39 (13) (2016) 2451-2458. https://doi.org/10.1002/jssc.201600045.

[14] Khosroshahi, A. M., Aflaki, F., Saemiyan, N., Abdollahpour, A., Asgharian, R., Simultaneous determination of paracetamol, 4-Aminophenol, 4-
Chloroacetanilid, Benzyl alcohol, Benzaldehyde and EDTA by HPLC method in paracetamol injection ampoule, Journal of Pharmaceutical and Health $\begin{array}{lllll}\text { Sciences } & 4 & \text { (1) 61-69. }\end{array}$ https://www.ingentaconnect.com/content/doaj/2228678 0/2016/00000004/00000001/art00004.

[15] Thomas, S. P., Poomali A., Development and Validation of RP-HPLC Method for Simultaneous Estimation of Paracetamol and Tramadol Hydrochloride, Indian Journal of Pharmacy and $\begin{array}{lllll}\text { Pharmacology } & 3 & \text { (4) (2016) 169-172. }\end{array}$ https://doi.org/10.5958/2393-9087.2016.00014.5.

[16] Abdelaleem, E. A., Naguib, I. A., Hassan, E. S., Ali, N. W., HPTLC and RP-HPLC methods for simultaneous determination of Paracetamol and Pamabrom in presence of their potential impurities, Journal of Pharmaceutical and Biomedical Analysis 114 (2015) 22-27. http://doi.org/10.1016/j.jpba.2015.04.043.

[17] Kalambate, P. K., Sanghavi, B. J., Karna, S. P., Srivastava, A. K., Simultaneous voltammetric determination of paracetamol and domperidone based on a graphene/platinum nanoparticles/nafion composite modified glassy carbon electrode, Sensors and Actuators B: $\quad$ Chemical $213 \quad$ (2015) 285-294. https://doi.org/10.1016/j.snb.2015.02.090.

[18] Yiğit, A., Yardım, Y., Şentürk, Z., Voltammetric Sensor Based on Boron-Doped Diamond Electrode for Simultaneous Determination of Paracetamol, Caffeine, and Aspirin in Pharmaceutical Formulations, IEEE Sensors Journal 16 (6) (2016) 1674-1680. http://doi.org/10.1109/JSEN.2015.2503436.

[19] Chitravathi, S., Munichandraiah, N., Voltammetric determination of paracetamol, tramadol and caffeine using poly(Nile blue) modified glassy carbon electrode, Journal of Electroanalytical Chemistry 764 (2016) 93103. http://doi.org/10.1016/j.jelechem.2016.01.021.

[20] Lima, A. B., Torres, L. M. F. C., Guimarães, C. F. C., Verly, R. M., da Silva, L. M., Carvalho Júnior, Á. D., dos Santos, W. T. P., Simultaneous Determination of Paracetamol and Ibuprofen in Pharmaceutical Samples by Differential Pulse Voltammetry Using a BoronDoped Diamond Electrode, Journal of the Brazilian Chemical Society 25 (3) (2014) 478-483. https://doi.org/10.5935/0103-5053.20140005.

[21] Wang, H., Zhang, S., Li, S., Qu, J., Electrochemical sensor based on palladium-reduced graphene oxide modified with gold nanoparticles for simultaneous determination of acetaminophen and 4-aminophenol, Talanta178 (2018) 188-194. http://doi.org/10.1016/j.talanta.2017.09.021. 
[22] Morelli, B., Spectrophotometric determination of paracetamol in pure form and in tablets, Journal of Pharmaceutical and Biomedical Analysis 7 (5) (1989) 577-584. http://doi.org/10.1016/0731-7085(89)802237.

[23] Nagaraja, P., Murthy, K. C. S., Rangappa, K. S., Spectrophotometric method for the determination of paracetamol and phenacetin, Journal of Pharmaceutical and Biomedical Analysis 17 (3) (1998) 501-506. http://doi.org/10.1016/s0731-7085(97)00237-9.

[24] Knochen, M., Giglio, J., Reis, B. F., Flow-injection spectrophotometric determination of paracetamol in tablets and oral solutions, Journal of Pharmaceutical and Biomedical Analysis 33 (2) (2003) 191-197. http://doi.org/10.1016/S0731-7085(03)00342-X.

[25] Xu, C., Li, B., Spectrophotometric determination of paracetamol with microwave assisted alkaline hydrolysis, Spectrochimica Acta Part A: Molecular and Biomolecular Spectroscopy 60 (8-9) (2004) 1861-1864. http://doi.org/10.1016/j.saa.2003.10.003.

[26] Othman, N. S., Zakaria, S. A. A., Spectrophotometric Assay of Paracetamol in Pharmaceutical Preparations, Journal of Education and $\begin{array}{llll}\text { Science } & 19 & \text { (3) } & \text { (2007) }\end{array}$ https://doi.org/10.33899/edusj.2007.51321.

[27] Shrestha, B. R., Pradhananga, R. R., Spectrophotometric Method for the Determination of Paracetamol, Journal of Nepal Chemical Society 24 (2009) 39-44. https://doi.org/10.3126/jncs.v24i0.2389.

[28] Vichare, V., Mujgond, P., Tambe, V., Dhole, S. N., Simultaneous Spectrophotometric determination of Paracetamol and Caffeine in Tablet Formulation, International Journal of PharmTech Research 2 (4) (2010) 2512-2516.

[29] Delvadiya, K., Kimbahune, R., Kabra, P., Sunil, K., Patel, P., Spectrophotometric Simultaneous Analysis of Paracetamol, Propyphenazone and Caffeine in Tablet Dosage Forms, International Journal of Pharmacy and Pharmaceutical Sciences 3 (Suppl 3) (2011) 170-174. https://innovareacademics.in/journal/ijpps/Vol3Suppl3/ 2178.pdf.

[30] Murtaza, G., Khan, S. A., Shabbir, A., Mahmood, A., Asad, M. H. H. B., Farzana, K., Malik, N. S., Hussain, I., Development of a UV-spectrophotometric method for the simultaneous determination of aspirin and paracetamol in tablets, Scientific Research and Essays 6 (2) (2011) 417-421.

[31] Behera, S., Ghanty, S., Ahmed, F., Santra, S., Banerjee, S., UV-Visible Spectrophotometric Method
Development and Validation of Assay of Paracetamol Tablet Formulation, Journal of Analytical \& Bioanalytical Techniques 3 (6) (2012) 1000151. https://doi.org/10.4172/2155-9872.1000151.

[32] Lawrence, O. A., Olufemi, A. G., Alex, O. D., Kayode, S. T., Spectrophotometric determination of acetaminophen content of different brands of paracetamol tablets from South-West Nigeria, Journal of Research in Environmental Science and Toxicology 1 (10) 251-257. https://www.interesjournals.org/articles/spectrophotom etric-determination-of-acetaminophencontent-ofdifferent-brands-of-paracetamol-tablets-fromsouthwest-niger.pdf.

[33] Kumar, G. V. S. R. P., Kumar, G. B., Sekhar, T. C., Murthy, S. B., Spectrophotometric Determination of Paracetamol Using Sodium bismuthate as Chromogen, International Journal of Research in Chemistry and Environment 2 (1) (2012) 231-235. https://ijrce.org/uploads/20/677_pdf.pdf.

[34] Al-Shwaiyat, M. K. E. A., Spectrophotometric determination of paracetamol by reduction of 18 Molybdo-2-Phosphate Heteropoly anion, Jordan Journal $\begin{array}{lllll}\text { of } & \text { Chemistry } 8 & \text { (2) } & \text { (2013) } & \text { 79-89. }\end{array}$ https://doi.org/10.12816/0001519.

[35] Ali, S. K., Analysis of Paracetamol by Oxidation with Potassium Iodate, Asian Journal of Applied $\begin{array}{llll}\text { Sciences } & 2 & \text { (2) 223-232. }\end{array}$ https://ajouronline.com/index.php/AJAS/article/view/1 284.

[36] Ahmed, R. K., Muhammad, S. S., Khodaer, E. A., Spectrophotometric Determination of Paracetamol in bulk and Pharmaceutical Preparations, Baghdad Science $\begin{array}{lllll}\text { Journal } & 12 & \text { (2) } & \text { (2015) } & \text { 317-323. }\end{array}$ https://doi.org/10.21123/bsj.12.2.317-323.

[37] Abdul-Raheem, M., Alsamarrai, K., Dikran, S., Spectrophotometric Determination of Paracetamol by Diazotization and Coupling Reaction with Anthranilic Acid, Ibn AL- Haitham Journal for Pure and Applied $\begin{array}{llll}\text { Science } & 29 & \text { (2) } & \text { (2016) }\end{array}$ 420.https://doaj.org/toc/2521-3407.

[38] Saeed, A. M., Spectrophotometric Determination of Paracetamol in Some Manufactured Tablets in Iraqi markets, International Journal of Pharmaceutical Sciences Review and Research 42 (2) (2017) 53-57. ISSN: $0976-044 X$.

[39] Iorhemen, R. T., Iorhemba, A. M., Sambo, R. E., Nande, W. U., Spectrophotometric determination of paracetamol in drug formulations with 1 - naphthol, 
International Journal of Advanced Chemistry 5 (2) (2017) 86-90. https://doi.org/10.14419/ijac.v5i2.8313.

[40] Younis, M. S., Othman, N. S., Indirect Spectrophotometric Assay of Paracetamol in Pharmaceutical Preparations, International Journal of Enhanced Research in Medicines \& Dental Care 5 (4) (2018)

23-29.

https://www.iasj.net/iasj?func=fulltext\&aId=88520.

[41] Alubaidy, G. F., Basheer, A. A., Saied, S. M., Thanoon, E. S., Spectrophotometric Determination of Paracetamol Using Diazotization Coupling Reaction, Rafidain Journal of Science28 (2) (2019) 76-83. https://rsci.mosuljournals.com/article_159979.html. 